\title{
Nallê Art: Notes on Some Aspects of Henna Application among the Kanuri People of Borno
}

\author{
Authors: Usman Al-amin \\ Submitted: \\ Published: \\ Volume: \\ Issue: \\ 30. July 2018 \\ 9. August 2018 \\ 5 \\ 6
}

Affiliation:

Languages:

Keywords:

DOI:

Abstract:

Centre for the Study of Manuscript Cultures, University of Hamburg

\section{English}

Kanuri, culture, henna, Borno, Nigeria

10.17160/josha.5.6.447

The culture of the Kanuri is predominately interesting and attractive. The Kanuri people are very obsessed with their culture which help the quality of cultural traits and vibes high. In Kanuri Culture just as in other ethnic groups throughout the world there are norms and values. Even though most of their culture finds its origin in the Islamic religion, yet they have a couple of traditions that are peculiar to the tribe. One of such traditions is the application of henna, which is not well documented by the social historians and anthropologists. It is based on this assertion that this paper makes attempt to examine the application and importance of Henna among Kanuri people. Henna or "nallê" as 


\title{
Nallê Arts: Notes on Some Aspects of Henna Application among the Kanuri People of Borno, Nigeria
}

By

\author{
Usman Al-amin, Halima Baba Shehu, Abdulsalam Abba Tor \& Alhaji Yakubu Babagana \\ Department of History \\ University of Maiduguri \\ Borno State, Nigeria.
}

alaminusman81@gmail.com

\begin{abstract}
The Kanuri are one of the largest tribal communities in Nigeria. The culture of the Kanuri is predominately interesting and attractive. Thus, the Kanuri people are very obsessed with and extremely proud of their culture which help the quality of its traits and vibes high; and also influenced other neighboring communities such Shuwa Arab, Hausa, Fulfulde etc. In Kanuri Culture just as in other ethnic groups throughout the world, tradition has a very important role to play in defining the sense of identity. Even though most of their culture finds its origin from the Islamic religion, yet they believe in them being the heirs of its existence. One of such traditions is the application of henna, which is not well documented by the social historians and anthropologists. It is based on this assertion that this paper makes attempt to examine the application and importance of Henna among Kanuri people. Henna or "nallê" as the Kanuri call it, is a safe and temporary body art practice for millennia among them. The paper shows that henna application was started in ancient time through traditional technique and due to influences of internal and external forces in the application, a new and modern techniques and designs emerged in Borno which could be regarded as the modern henna application. The results of the examinations revealed three distinct techniques of henna application in Borno. Henna is traditionally used for special occasions, inter-alia weddings, naming ceremonies and other festive seasons, and is a symbol of beauty, art, happiness and it shows brides readiness for the wedding to come. The study adopts the historical narrative and analytical approach and concludes that apart the social role of Henna, it equally has very important religious functions among Kanuri men. Kanuri men use the dye to colour their beards, which was strongly considered as prophetic or prophet's tradition. Finally, the study submitted that henna application has been seriously affected by the greatest forces of globalization.
\end{abstract}

Keywords: Kanuri, culture, henna, Borno, design, pattern, technique, Nigeria etc. 

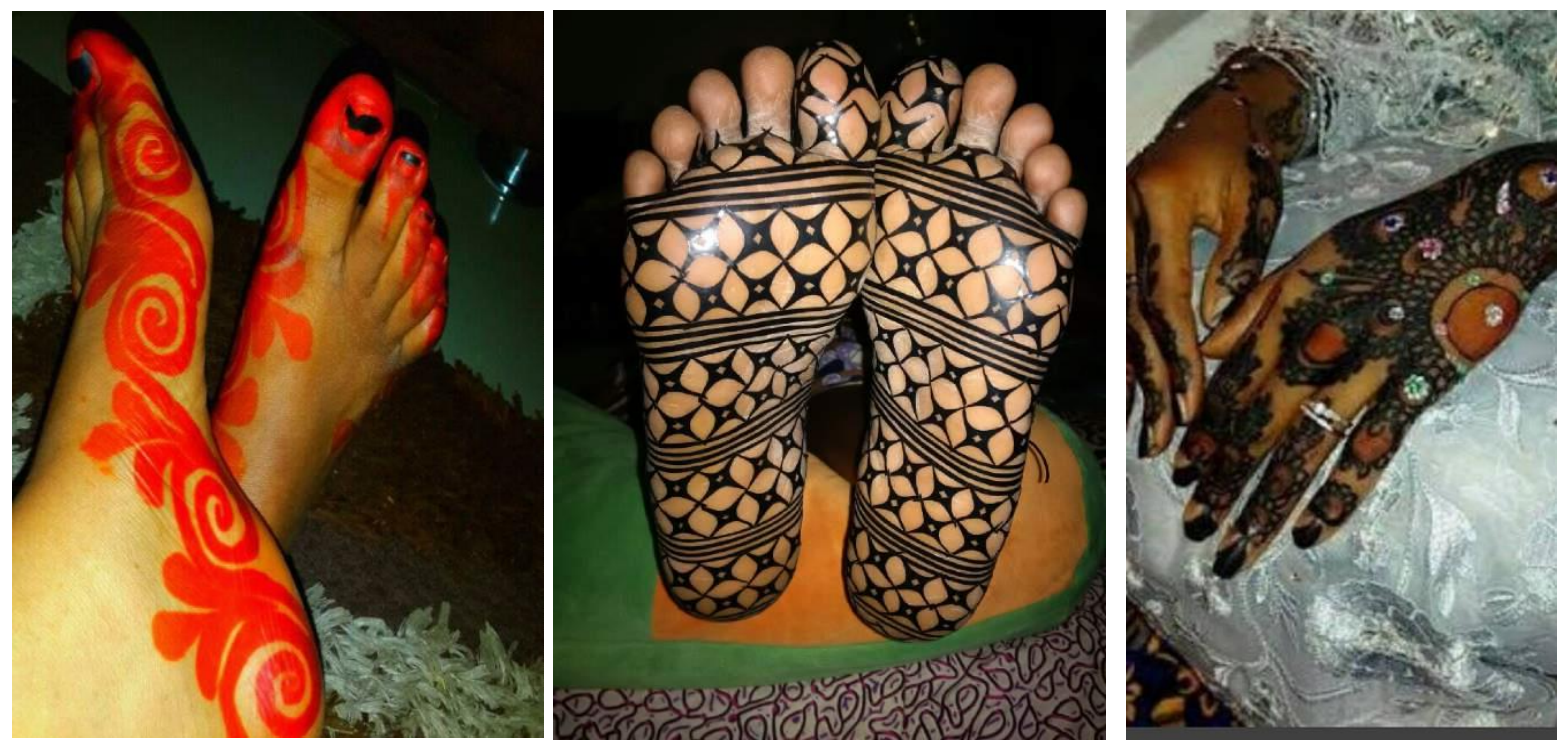

Background to the study

The Kanuri are one of the largest groups of people in Nigeria. Most of them live in an extensive area of north-eastern Nigeria, whose outstanding physical characteristics are widely separated, densely populated towns and gently undulating, farmed countryside scattered with trees and hamlets. Muhammad Nur Alkali stated that Kanuri refers to a language, the people who speak the language and much of the social organization of the Kanuri's has been influenced by Islam. ${ }^{1}$ He also affirms that the many branches such as Manga, Mobar and Bodawai are the major groups that formed the Kanuri language and the Kanuri's speak any of its major dialects. ${ }^{2}$ For the purpose of this work, the Kanuri's refer to the principal people of Borno who are considered to be a mixture of Arab and Negro communities established in the area for many centuries and they can still be found east of the Chad Republic, an area which covers the greater part of the Kanem Empire. Opoku and Bulakarima, ${ }^{3}$ posited that the Kanuri language was the lingua franca of ancient Kanem-Borno Empire. ${ }^{4}$ Today, it is widely spoken across Borno, Yobe and Jigawa States in present day Nigeria as well as in large part of Niger, Cameroun and Chad Republic. Kanuri have distinct unique cultural identities. The central factor of the Kanuri culture is the religion, Islam, was the heart of the state and symbols its unity and continuity. It was not by accident that Islam blends religion and culture inextricably together. Kanuri culture itself

\footnotetext{
${ }^{1}$ Muhammad Nur Alkali 1987: 1-14.

${ }^{2}$ Ibid.

${ }^{3}$ O. Kwame and B. Umara, 1988: 1 .

${ }^{4}$ In this study the term "Kanuri" will be used throughout to refer to both the people and the language as well as their character.
} 
practiced (as in Borno) with an Islamic tinge, including the naming and marriage ceremonies, funerals etc. This influence is not limited to the socio-religious life, but to all aspects of what scholars refer to as the "cultural fabric" of society. Their creative ingenuity is expressed through handicrafts, especially in weaving, dyeing, blacksmithing, carpentry, henna application, basketry, etc. which essentialised the Kanuri cultural heritage and the ethical standard-the Kanuri ideal culture. The hands, feet, nails and arm of the Kanuri women are always full of henna designs and arts. Henna application is very common practice among the Kanuri and occupies the central place in Kanuri's body arts. Unfortunately, scholars give little attention is paid to the henna application among the Kanuri and its history, techniques both in traditional and modern settings, tools, ingredients, design patterns, significance etc.

This state of relative neglect has provided much of the initial impetus for this paper, which demonstrates the kind of artistic work of henna application among the Kanuri of Borno. Specifically, it looks at the history, techniques, design patterns and significance of the henna application, the tools and ingredients for making it, the new developments related it. Each in its ways is an attempt to create balance in our understanding of one of the world's great culture. But the subject is too vast and even too diffuse. What is presented here is a small sampling of the subject matter. The paper shows that henna application was started in ancient time through traditional technique and due to influences of internal and external forces in the application, a new and modern techniques and designs emerged in Borno which could be regarded as the modern henna application. The results of the examinations revealed three distinct techniques of henna application in Borno. First, the traditional technique which has no or less design patterns and is common to traditional people all over Nigeria, the second technique is by using tape to create to the design patterns and use rani to make to mix the henna while for the third technique, almost ready-made product is used called "sajaan" is used to draw the design patterns and less amount natural henna is used. This exposure and experience, which was the first of its kind in Borno is seen as the beginning of modern henna application not only in Borno where it probably started among the Kanuri people in Borno but in Nigeria, and therefore, the Bornoan experts of the henna application are hired to go to other parts of Nigeria to do the artistic work of henna. The paper shows Henna application is the expression of a people's genius, it will only survive if it able to find its own national style and recognition. This paper examines how this new development has contributed in a positive direction to the development of contemporary henna 
application in Nigeria as a new art in technology. Although the henna application among the people of Borno in Nigeria is used as paradigm of this study and the research results reported in this paper are essentially drawn from them, they have relevance to many other places in Nigeria and Africa.

\section{Objectives of the Study}

This paper deals with primarily with the henna applications among the Kanuri people of Borno, Nigeria. The specific objectives of the paper are:

1. To examine the history of henna application with a with view of determining the ownership in Borno.

2. To investigate the techniques and design patterns of henna application among the Kanuri in Borno and beyond.

3. To determine the significance of henna application in Borno, by examining its social, cultural and economic relevance.

\section{Methodology}

Data collected and analysed were essentially primary. Many people with various experiences comprising the artist, users, patrons, and historians were randomly interviewed. Most of the artists and users had adequate experience ranging from 1 year to 40 years. Secondary data published, and internet henna application information were virtually used. The study is organized into four main parts. The first part deals with the history of the study area and henna application as well as its sources and ownership. The second part looks at the the techniques and design patterns of henna application among the Kanuri in Borno and beyond. This leads us to the importance of henna application from the different perspectives. Part four is recommendation and conclusion.

\section{Study Area}

The Kanuri of Borno have one of the oldest known social and cultural histories in Africa, being one of the oldest extant empires in the world. ${ }^{5}$ Its founder, Mai Umme Jilmi, who reigned from 1088 to 1097, popularly referred to it as the first Kanuri Empire, with the capital Njimi at Kanem in Chad. The empire has survived into the $21^{\text {st }}$ century. Borno became the melting pot of several peoples (from which the Kanuri emerged as the dominant group) because of its

\footnotetext{
${ }^{5}$ The exact historical beginnings of Borno are buried in the sands of the Sahara and the archeological factors that entered its origin cannot be enumerated here. For more on this see J.F.Ajayi \& Michael Crowder, History of West Africa London: Longman, 1974.
} 
strategic geographical setting. According to the information on geography and population in the Borno State Executive Diary (2000: 1-6), Borno State lies in the north eastern part of Nigeria between latitudes 10 degrees: 02 ' $\mathrm{N}$ and 13 degrees: 04' $\mathrm{N}$ and longitude 11 degrees: 04' $\mathrm{E}$ and14 degrees: 04'E. It is the largest state in the Nigerian Federation in terms of landmass, covering an area of $69,436 \mathrm{Km}^{2}$. Its neighbors within the country are Bauchi to the southwest, Yobe to the west and Adamawa to the south. Occupying the greater part of the Chad Basin, Borno shares borders with other countries: Cameroon to the east, Chad to the north - east and the Republic of Niger to the north. The total population according to the 1991 census was 2, 533,033 with a population density of 38 inhabitants per square kilometer. Borno State is pluralistic in ethnic composition with about thirty languages represented, many of which are autochthonous. Twentysix of these languages are classified as Chadic by linguists, while Kanuri (the largest language and ethnic group) is classified as Saharan. Nineteen out of the twenty-seven local government areas are Kanuri-speaking. Kanuri have culturally influenced its neighbors and played an important role in the political and cultural history of the whole Borno.

\section{Historical Context of Henna Application}

One Every culture has a starting point but for the henna application in Borno, very a few prehistoric remains attest to the point. The historical records available in huge numbers, the English name "henna" is doubtlessly from Arabic word $\underset{\sim}{\longrightarrow}$, pronounced hinnā. ${ }^{6}$ A linguistic analysis suggests that the use of henna had originally spread in West Africa via the Amazigh and Tuareg communities of the Sahara, since the word used for henna in the 17th-century Borno by the Kanuri. According to different sources, the Kanuri nallê was borrowed from Tuareg ${ }^{7}$ which was later borrowed into Hausa and Yoruba as lallèe. ${ }^{8}$ This form like the Kanuri form occur in several other languages in the region: Teda-Daza: lelle, ${ }^{9}$ Dendi: làllé, Zarma: lálé, ${ }^{10}$ Kaado: lélé. Among the Kanuris, the name nallê is also used for dye or paste derived from the leaves of the plant, and for the art of temporary tattooing from those paste. Nallê or henna, which is binominal known as lawsonia inermis, is a flowering plant extract from the leaves of this plant have been used since the Bronze Age period to create a natural red-brown dye, used to colour skin, nails,

\footnotetext{
${ }^{6}$ Gouffé 1971-72:163; www.hennaarts.com/henna-faq.htm accessed on 20.07.2018.

${ }^{7}$ Maarten Kossmann 2005: 71.

${ }^{8}$ Ibid; see also Noam Sienna 2016.

${ }^{9}$ Lukas 1953: 191.

${ }^{10}$ Bernard \& WhiteKaba 1994: 342.
} 
hair, leather and wool. ${ }^{11}$ Below are the pictures of henna plant and leaves, and a woman grinding it. $^{12}$
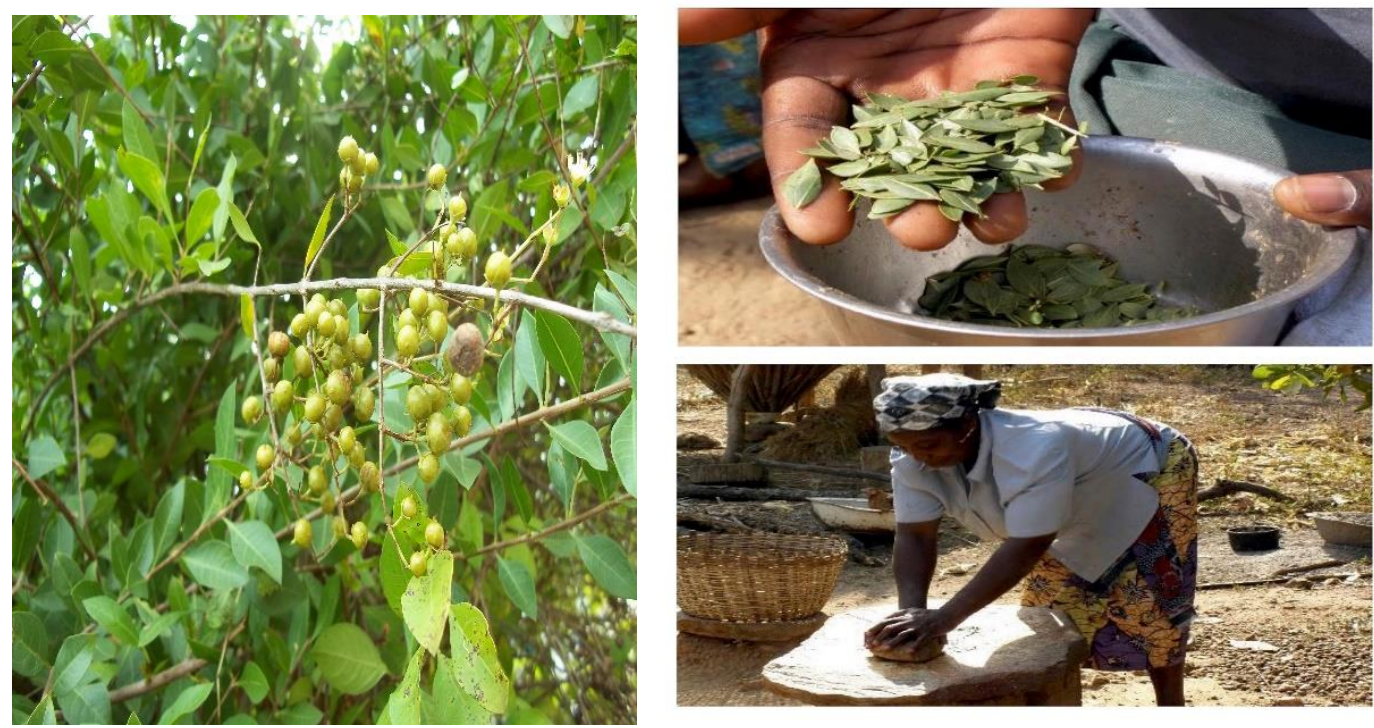

Many origin traditions of henna application exist and therefore locating the actual source has become largely speculative. One origin story has it that the plant is native to tropical and subtropical regions such as Asia (South Asia in particular), Africa and some parts of Australia. Equally, it is commercial cultivated in many countries, Interalia-India, Pakistan, Saudi, Egypt, Sudan, Nigeria etc. ${ }^{13}$. it is important to know that the shrub, which is also called "Al Kanna" and "Mignonette" tree, grows in moist places. The plant bears small, fragment and a white rose flower in clusters. This often-spiny shrub, which grows up to 20 feet high, is cultivated as an ornamental in many parts of the world. The numerous fragments flowers in panicles range from red, through rose-pink, to white. The land shaped opposite leaves are short stalked and may reach $1 \frac{1}{2}$ inches in length. The fruit is capsular in nature, and the plant may be propagated by seeds and equally via cuttings. ${ }^{14}$

The ancient city of Maranda (meaning itself "small leaves of Egyptian privet"), which was in rapid decline in the $12^{\text {th }}$ century A.D., was known to be a major producer of henna. As mentioned hitherto, the extracts from the leaves of henna plant have been used since the Bronze

\footnotetext{
${ }^{11}$ Funk and Wagnalls 1965: 589.

12 Noam Sienna 2016.

${ }^{13}$ Interview with Ba Mammadu Daboa at Bana on $11^{\text {th }}$ June 2014.

${ }^{14}$ Bosoghu A. Burdance \& I Solmaz 1998: 1-3.
} 
Age period to create natural red-brown dye used to colour skin, nails leather, wool etc. thus, according to available sources, henna was used as hair dye by an Egyptian queen during the third dynasty (2780-2790 BC) ${ }^{15}$. Same source equally maintained that the mummies of ancient Egypt (since time out of mind) have been found wrapped in Henna-dyed cloth. From time immemorial, henna is traditionally use in various festivals and occasions. For instance, there is mention of Henna as hair dye in Indian courts records around 400BC: ${ }^{16}$ Notwithstanding, henna was also listed in the medical texts of the Eberd Papinis (16 ${ }^{\text {th }}$ century BC Egypt $),{ }^{17}$ and by Ibn Qayyum Al-Jawziyya $\left(14^{\text {th }}\right.$ century BC Syria and Egypt) as medical herbs. ${ }^{18}$

Not much documentation exists on origin of henna application in West Africa. According to Noam Sienna, henna has been a part of West African culture for at least a thousand years and it has been mentioned in Kitāb al-Masālik wa-al-Mamālik ("The Book of Roads and Kingdoms") written by medieval Andalusi geographer al-Bakri (ca. 1014-1094). ${ }^{19}$ In fact, this information is reputed by scholars and suggested that al-Bakri is likely borrowing this information from the 10th-century writer al-Warraq ${ }^{20}$ Henna is also documented that henna was apparently also grown in the medieval city of Marandi in central Niger. ${ }^{21}$ It is also mentioned in Hausaland throughout the Middle Ages and early modern. ${ }^{22}$ For long time the works of Adanson (1757), Hogben (1967), Fletcher (1912), Clapperton and Denham (1826) and Clapperton (1829), remained reference points on henna application, until Noam Sienna (2016)'s insightful, monumental and over-ambitious contribution. This work is a profound tapestry of the totality of henna application in West Africa.

Use of Henna for body art and make-up fashion has enjoyed a recent renaissance due to improvement in cultivation, processing and the migration of people from traditionally henna producing and using regions to other places. ${ }^{23}$ The orange-red dye produced by the leaves of henna is used extensively by the women of Muslim countries and Hindu women to stain the nails and tips of their fingers and parts of their feet's, also men of these countries (Muslim countries in

\footnotetext{
${ }^{15}$ Funk and Wagnalls 1965: 589.

16 Ibid.

${ }^{17}$ Importance of Henna among South-Asian Women retrieved from www.salamstock.com

18 Ibid

${ }^{19}$ Noam Sienna 2016.

${ }^{20}$ Ibid.

${ }^{21}$ Ibid.

22 Ibid.

${ }^{23}$ Henna and its History Among Arab Women, accessible at www.fashionandcustome.com
} 
particular), use the dye to colour their beards, which was considered as the "Sunnah" or tradition of the prophet (S.A.W. ${ }^{24}$. Equally important, the orange-red dye is used in no small way in the western world too, particularly in the United States of America as a rinse to impart a reddish colour to hair. ${ }^{25}$ The dye is also used to stain leather and hides and to colour the hoofs and manes of horses ${ }^{26}$. It is also significant, to know that, henna contains natural anti-bacterial and anti-viral elements, and the two compounds-lawsome and isoplimbagin, have shown help to prevent skin cancer. ${ }^{27}$ Added to the above, henna flowers have been used to create perfume since ancient times and it was also used in repelling some insect and mildew. ${ }^{28}$

\section{Henna in Borno}

Borno in general has a high reputation in henna application in West Africa but with obscure history. It is difficult to mention precisely the exact date when henna was first introduced into the area of our study i.e. Borno of Northern Nigeria. For the dearth of reliable history records, there is also scarcity of documented history on when Kanuri people was started using henna. While some suggests that Fulani were responsible for the introduction and extension of henna to Borno, Kotoko and to Baghirmi. ${ }^{29}$ Others claimed that it has been there even before the arrival of the colonial masters and this fine art remains popular to this day. ${ }^{30}$ One traditions maintain that, the use of henna was introduced together with Islamic culture, since the aspect of Islamic culture that has been most readily taken in the area is that of henna, and this is because the technique, style, and religious importance attached to it, would have been greatly stimulated by outside Islamic influence, particularly from the Islamic world. The third assertion might be true because Kanuri have never been a static or isolated people as is evident throughout the oral tradition. And when encounters with Islam and with Europeans, many Kanuri cultural rites were impacted by them. Islam and European impacts on Kanuri are not limited to the culture but also in the language and on literature. However, in most of African cultures, the essence of henna application is linked with Islam and generally regarded as having some blessings (baraka).

\footnotetext{
${ }^{24}$ Interview with Shiekh El-Mustapha at Dikwa on $20^{\text {th }}$ August 2014 and Mallam Alirambe Gayibo.

${ }^{25}$ Funk and Wagnalls 1965: 590.

26 The American Peoples Encyclopedia, New York, 1965. 423.

27 American Journal of Medical Science, 1980: 19.

${ }^{28}$ Interview with Karu Mala at Maiduguri on $1^{\text {st }}$ June 2014.

${ }^{29}$ Jack R. Harlan et al 1976: 255.

${ }^{30}$ Henna at https://allafrica.com/stories/201311260072.html accessed on 20.07.2018.
} 
Besides all these, the henna application (nallê) has been a long-standing tradition among the Kanuri people but is mostly known today for its relevance and prevalence in Borno. For the Kanuri, the arts or design patterns has always been an extraordinary importance. Because it used to make woman more beautiful and provide visual embodiment of bride. In fact, the main wedding activities of the Kanuri people start on Thursday with yum nallêye or henna day, which is used by the bride and other females in attendance to decorate their hands and legs. This culturally and officially signifies the opening for the wedding events. Each with its own unique design and features and associated with different occasions and situations. Technological advancement and the social media in the internet are the other agents that tempered the traditional technique of henna application in Borno.

\section{Ownership of Henna}

Trees and plants occupy very important place in Borno. Kanuri people have been growing trees and plants since time immemorial. It is a well-known fact that human life cannot co-exist without plant and trees. Plants and their products are parts of the human life in all ramifications. Kanuri people has several ways in which they may claim the ownership of plant, depending on the place where it grows or who plants it. Traditionally, henna was a farm-hedges or boundary-plant, mainly grow in small fenced plots. When the plant was still in the forest or bush it belong to anybody who wished to make use of it, but after the plant had been cut and collected from bush or just cut and arranged to but left in the bush, ownership was claimed. ${ }^{31}$ Ownership began when one first worked with a plant, one cannot claim a natural object if the source of the seed is unknown. The claims for ownership are stressed by responding that: "It is my tree because I or my ancestors planted it" or "It is mine because it grows on my farm or fence"; and so on, otherwise the claim is not valid. ${ }^{32}$ In Nigeria, henna is planted for the of the leaves in the beginning of twentieth century to date. ${ }^{33}$ The dried leaves are easily storable during the dry season, but not during the rains when very severe price fluctuations are apt to occur. Sometimes sold on the bush, the leaves are plucked by men and traded after drying. While a small number of the secluded women sell the leaves, most supplies are traded by men, some of whom are strangers. The henna plants are grown locally, but some of the ingredients and designs of henna application have being importing from India and Muslim Arab.

\footnotetext{
${ }^{31}$ Interviewed with Malam Muhammad Abdulqadir on phone on 1.08.2018.

${ }^{32}$ Ibid.

${ }^{33}$ John M. Dalziel 1916: 70.
} 


\section{Techniques of Henna Application}

Nallê as the Kanuri called, it is a safe and temporary body art practice for millennia in Borno, among the Kanuri. ${ }^{34} \mathrm{Henna}$ application is an art of beautifying the parts of the body which includes leg, hand, fingers, chest, and back, which are mostly done and displayed during marriage, naming, ceremonies and festivals. It is done through different techniques but for now three types of techniques of henna application, are specifically determinable. A method which more popular among the Kanuri traditional people is somehow indigenous technique. In this technique, pure and natural greenish henna (lawsonia inermis) is used. The dried leaves of this cultivated perennial shrub (Egyptian privet), which may flourish for many years, are pounded and made into a paste with hot water which, usually by bandaging with polybag (but sometimes by immersing the arm in a cylindrical gourd called zunguru), the calabash gourds would be hollowed out, dried and decorated, and then filled with henna; then it could be put over the hand and left on to obtain a very deep stain in one or two hours. The dye stuff is then removed, and washed, leaving beautiful stain on the nails, body or the skin. The first picture is the henna gourd (zunguru), $20^{\text {th }}$ century ${ }^{35}$ and the second picture is a Hausa woman after applying henna, ca. 1900. Her feet are wrapped with rags, and her left arm is in a decorated henna gourd. ${ }^{36}$
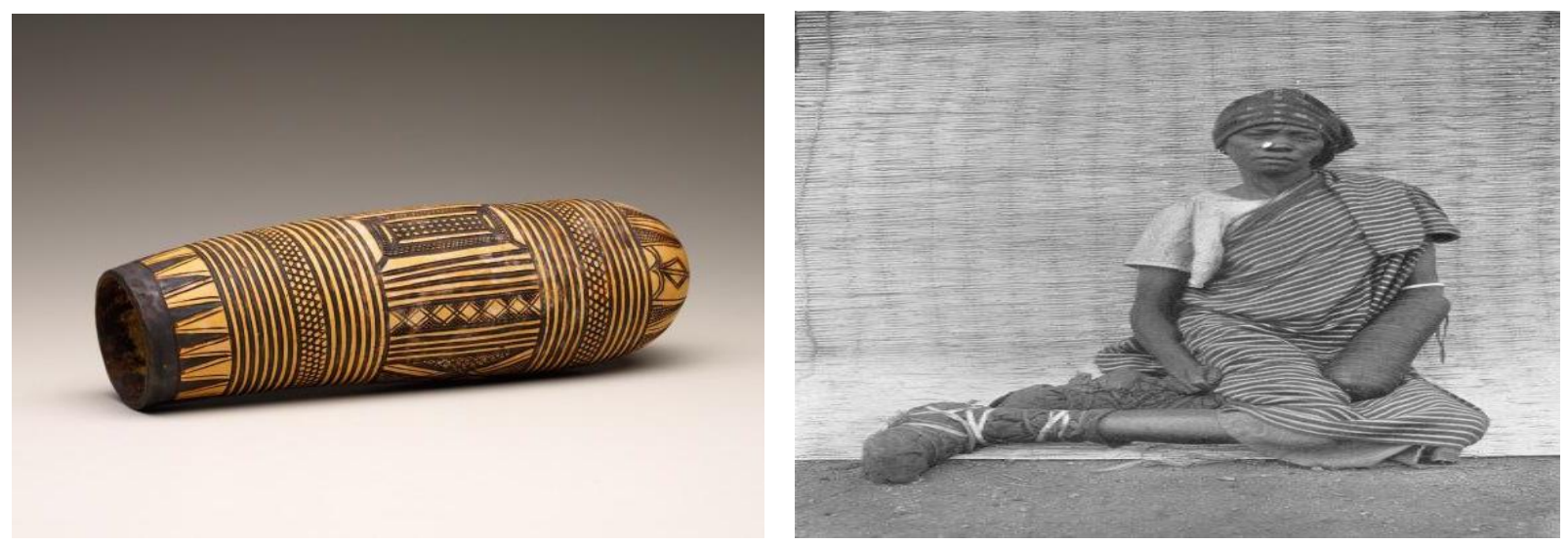

The traditional technique is popularly called "dungulumi" among the Hausa people, though slightly varies, had been very popular and is of great considerable importance in traditional West African societies including Kanuri people. Throughout the history of Borno, traditional technique could be practiced by any woman, whether she was a professional artist or an ordinary woman. In Borno State, like other states in the country, the traditional technique has

\footnotetext{
${ }^{34}$ Ibid, Interview with Karu Mala

${ }^{35}$ Noam Sienna 2016.

${ }^{36}$ Ibid.
} 
been abandoned and only maintained by old Kanuri people within their domains. It is indeed a mark of cultural misdirection to stop the technique for whatsoever reason because it is one of the important cultural features that must be nourished, reinvented and kept extant.

As a society evolves, there comes a time when change is not only inevitable but is also a necessary concomitant for the development of society. Thus, the traditional method of henna application in Borno, has been internally and externally affected by strong cultural forces of change. Cultures are internally affected by both forces encouraging change and forces resisting change. These forces are related to both social and structures and natural events and are involved in the perpetuation of cultural ideas and practices within current structures, which themselves are subject to change. ${ }^{37}$ Social motives and the development of technologies can produce changes within a society by altering social dynamics and promoting new cultural models, and spurring or enabling generative action. ${ }^{38}$ Like all societies in transition, the Kanuri society is a dynamic one and has experienced elements of social transformation with respect to cultural traditions caused by education, population growth, technological changes, modern health care, and the effects of mass media. All these changes have led to the modernization of the henna application among the Kanuri people. There is thus a clear impact of globalization on the henna art in an era where the entire world is referred to as one "global village" is visible. Globalization is facilitated by ease of communication that comes with handy, computer networks and television that promoted the widespread of photos and ideas of new designs, models, techniques, tools, ingredients of henna application and its importance. All the changes described above regarding henna application are far more evident in urban than in rural areas.

Cultures also externally affected via contact between societies, which may also produce or inhabit social shifts and changes cultural practices. Additionally, cultural ideas may transfer from one society to another, through diffusion or acculturation. In diffusion, the form of something (though not necessarily its meaning) moves from one culture to another. Acculturation has different meanings, but in this context refers replacement of the traits of one culture with those of another, such has happened to certain many cultures across the globe during the process of colonialization. Related processes on an individual level include assimilation (adoption of a different culture by an individual) and transculturation. Because of this, henna

\footnotetext{
${ }^{37}$ Lindlof \&Taylor 2002: 60.

${ }^{38}$ Sunday Enessi Ododo 2014: 5.
} 
application has witnessed many developments in terms of technique, design, tool, and its importance. In considering modern changes brought about to the technique of henna application, we can determine two major processes. By first modern technique, the patterns are created with thin strips of tape using razor blade and put on hands or feet, and then the henna is applied thickly over top. Unlike Hausa people who use tape to create small densely-patterned designs, most Kanuri patterns use are big geometric designs of stripes and stars on a fully-hennaed background. ${ }^{39}$ To mix henna for application, start by buying rani or grounded leaves of pure natural henna in the shade that you want. Pour the rani or henna powder into a ceremic, plastic, glass, or stainless-steel bowl and gradually add water or oil, stirring constantly, until the henna mixture is consistency of yogurt or paste which is then applied in intricate designs directly on the body or skin properly, but the recipe varies greatly from place to place, and every artist has his own style and method. ${ }^{40}$ Thus, after the application of the paste, the area will take sometimes to dry and finally wash. The below pictures are of both the design pattern made up of tape and the finished henna.
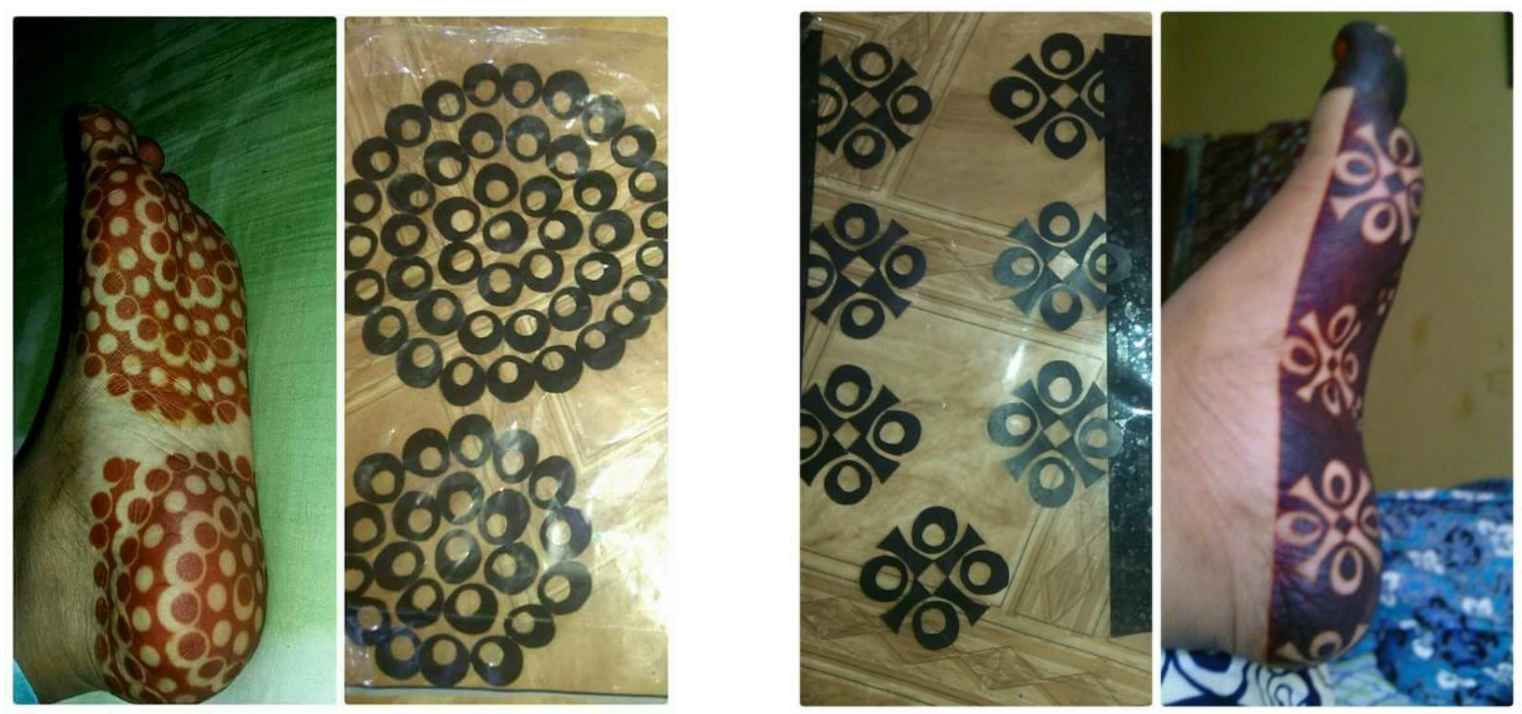

This recent innovation is generally regarded as the starting point of the modern techniques in henna application in Borno. The Second modern technique is most of dye and is blackish in colour. The henna paste is normally bought in a container shaped like toothpaste or writing maker. It is henna paste is applied on skin just like you are drawing on board. After

\footnotetext{
${ }^{39}$ Noam Sienna 2016.

${ }^{40}$ Op.cit, Importance of Henna Among South Asian women.
} 
henna is applied, the designs are left to set for several hours, giving time for the dye to colour the skin. In this techniqueThe illustration is in the picture below:
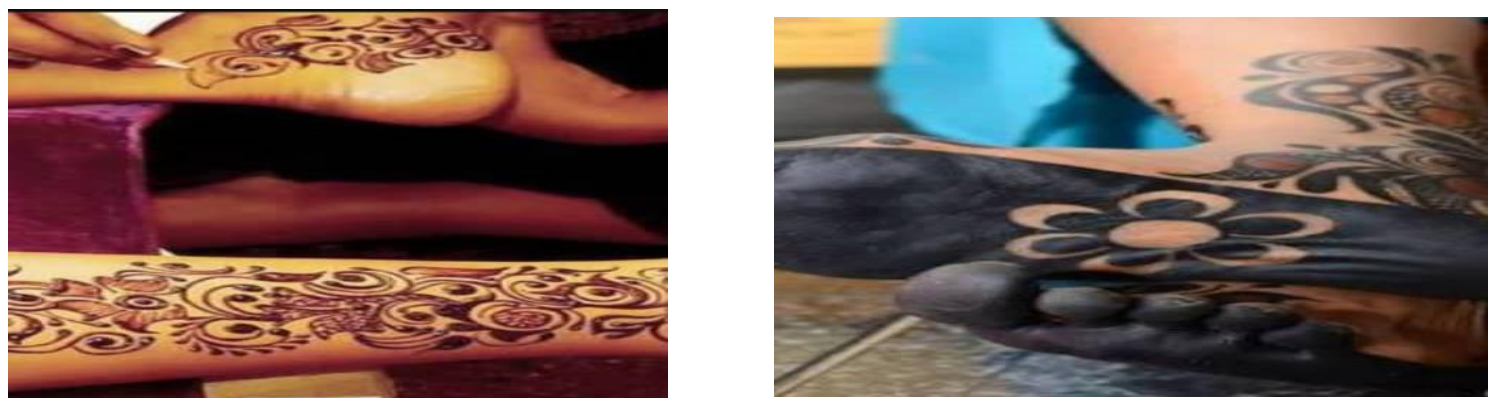

Thus, as claimed by Ya' Zarah Saleh (a henna decorator) because every body's hair, nail and skin differ from one another equally every one's body will get a different outcome when they use henna on their body. Henna design on hands of a bride may take anywhere from one hour to two hours. Traditional techniques in Borno have not diminished in influence, and their ongoing practice may be attributable to Old people or for religious and medicinal purposes.

While for the beard, for instance, if one desire the most vibrant reddish result possible then the beards is to be covered in henna and wrap the bear up in film, this will stop the curetting to the henna and oxidizing it giving one a more vivid hue. Also prefer a richer brown color, then he can either leave the bear uncovered or wrap it lordly in an old towel or wrapper. Thus, one should leave the henna for at least an hour or more for the best possible result. He also said that if one is feeling creative and fancy for making his own unique shade and style he can leave it much longer on the bear for the desire colour to show vividly a style which men of nowadays mostly desire.

\section{Lasting Period}

The colour oxidized to a dark reddish brown and then fades naturally over two or three weeks, depending on the area of the body applied and the skin chemistry of the person involved. ${ }^{41}$ It is worthy of note that because due to differences in human body, hair, nails or skin, people get different outcomes when henna is applied ${ }^{42}$ For longevity of henna color, we suggest less washing of the body part where henna is applied and less use of soap. Water proof adhesive and glitter that lasts for several days and is removable with denatured spirit or petrol.

\footnotetext{
${ }^{41}$ Interview with Karu Mala.

${ }^{42}$ Interview with Ya' Bawa, Maiduguri on $2^{\text {nd }}$ June 2015.
} 


\section{Design Patterns}

In Nigeria today, some henna arts and patterns are nationally recognized as the henna arts or design patterns of some people, especially the Kanuri, Hausa, Fulfulde, Yoruba etc. Kanuri henna, arts and patterns used to occupy preeminent space and consciousness in Nigeria and beyond. It is not only because its long history in the area but for their mastery and captivating design patterns. The popularity that Kanuri pattern enjoy today is due to the innovation in the technique and deliberate promotional stunts to increase patronage for them. The land of Borno, like other parts of Nigeria, applies henna in a similar style. Although design and experience for the application of the henna may differ from one locality to another, the process of designing design patterns is the same all over. Even though Naom Sienna identified as slight regional variation among Mauritanians whom used small pieces of tapes to create densely patterns, the simple nature of its artistic design patterns and style notwithstanding, has not changed with another parts West Africa.

One very common design pattern to henna application in the traditional Borno is less artistic work and simple in nature. The modernity and technological advancement have also influenced the design patterns in so many ways. There is a range of design patterns which require the help viral pictures and videos before they are drawn or designed. The internet is the main source of the beautiful designs and way of advertising the business. Some of the design patterns are of Arabic and Indian styles which have been mainly connected with bold flowers, flowering shapes, stars, ball, lovely geometric or calligraphic style, sometimes henna is applied on the body or skin to match with the bride's dressing or weeding attire in cooperating special outing. The designs are sometimes quite like the artistic works on the calabash use by the nomadic Fulani woman. The varieties are so wide that it is difficult to categorize them but some of these design patterns are given below and appendix. Mostly the design pattern defends on the choice of the person involves and the talent of the artist. Because of the popular nature they are often

presented as samples to new brides to choose for themselves. The question which most frequently asked about Kanuri henna art is whether the designs that are used have any special meaning. In answering this critical question, I interviewed a good number of the artists who responded that the designs have no any meaning in whatsoever form. 

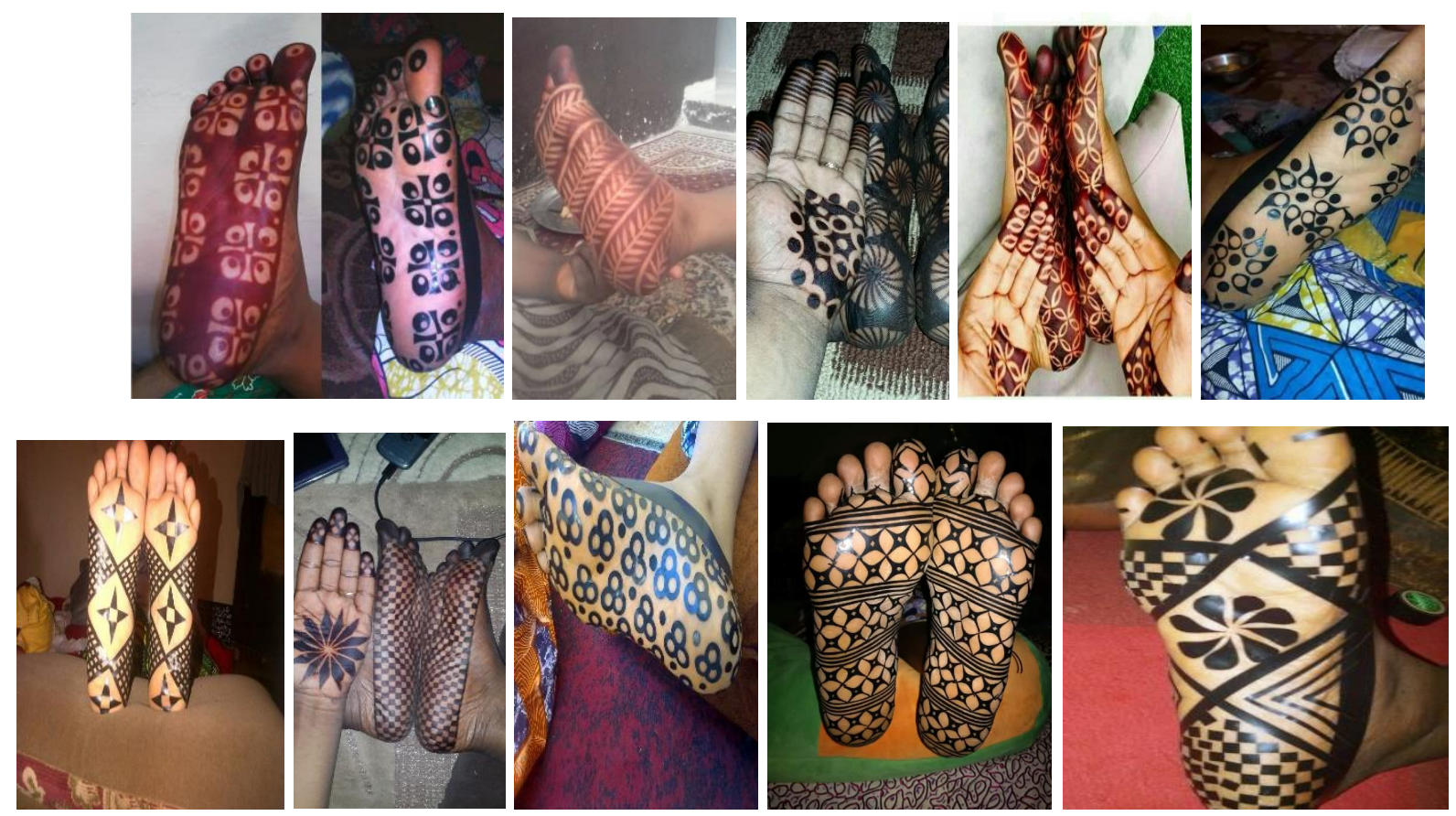

\section{Significance of Henna Application}

Across the world, womanhood is essentially adored and revered and therefore, henna application is important to any fashionable human society. The Henna application is a culture which is commonly practiced among the peoples of various ethnic groups of Nigeria to enhance beauty and for aesthetic, religious, commercial and ceremonial purposes in both everyday life and in marriage and childbirth rituals. Henna has both moral and social significance among the Kanuri people of Borno, because henna has been playing a major role in the wedding process, naming ceremonies, installation of kings and chiefs, and other festive periods. ${ }^{43}$ The significant aspects of these positive values, which is our concern in this paper, is the understanding of all cultural and traditional value attached to it in the marital process or life of the people, because a whole day (mostly the last Thursday before the marriage day) is dedicated to it, which is referred to as "yum nallêye" meaning henna day. Equally, a whole week or so is dedicated for henna to be applied on the nails, legs, feet and hands of the bride, a process the girls of nowadays called or referred as "dilki". On that very day of yum nallêye, the bride her friends, family and relatives get together to celebrate the weeding to come. As usual, the henna is brought to the bride's home by

\footnotetext{
${ }^{43}$ Ibid.
} 
the groom's family. Traditionally, this period is filled with music (popularly referred to as dumba) and dance performances by those closest to the bride's family while the bride get extensive and expensive henna patterns done on her hands and feet, two days prior to wedding day so that they can enjoy the festivities and have a deeper stain by the wedding day. In fact, this practice enjoyed a long tradition among the Kanuri people. It also helps to extend the beauty and fashion sense of women and make their skin very soft. It is in recognition of this importance that James Grey Jackson ${ }^{44}$ remarked that:

The Herb, with decoration of which they dye their nails and hands, is called by the Arabs El Henna: it imparts a coolness and softness to the hands and diminishes the excessive perspiration incident to warm climates.

The importance and linkages of henna application for the observance of religious obligations is a settled matter, which featured prominently in religious practices such as healing, festivals and worships. In Borno, for example, it occupied prominent old people their beards are grey (especially among the so called ahl-sunnah) who make use of it to colour their beards, which is strongly considered as the tradition of the prophet and this has been in practice since the eleven country A.D when Islam was first introduced to Kanem. Roland Fletcher, a British military officer stationed in Nigeria from 1904-1914, gives an interesting story about the origin of henna use, attributing it to Fatima, the daughter of the Prophet, reads as:

Nana Fazumatu [Fatima], a daughter of Mahomet, married one Saidi or Sidi Ali. One day she was lying beside her husband, who had fallen asleep on her right arm, when the Prophet arrived at the house. She had then to choose between two unseemly actions, namely, to waken her husband, or to keep her father waiting at the door. From this dilemma she freed herself by taking a knife and cutting off her right arm. The blood flowed out on to a henna shrub growing near, which has ever since provided the blood-red stain in common use. On greeting her father, she discovered that a new and more comely arm had

\footnotetext{
${ }^{44}$ James Grey Jackson 1967: 512.
} 
miraculously grown in place of the one she had sacrificed. ${ }^{45}$

Of a fact, there are many derivable social benefits when a bride is adorned with henna. Essentially, henna improves the beauty of the bride and symbolizes prosperity happiness, generify and in most of marriages, it shows the bride's readiness for the marriage or weeding. Henna can provide beauty as well as designs, can provide needed nourishment for the human eye and psyche, as well as to serve sex arouser. In fact, Kanuri bride-to-be, no matter how welldressed, will not be deemed complete until her hands and legs are painted with the liquid fluid made locally with henna (leaves). ${ }^{46}$ That is why it is crucial to adorn all brides with henna and sack or sacks of henna leaves becomes part of the Kanuri wedding.

It is interesting to note that all our respondents believed that henna application serves as a social stratum among the Kanuri people of Borno. For example, one of our sources maintained that, due to the long tradition of henna usage among the Kanuri people a Kanuri person can simply recognizes or identify and distinguishes between married and not married women or divorce and widow by the type of henna applied on their bodies. Thus, it further said that during the olden days, it was only married and divorced women that applied henna on both their hands and legs, whereas unmarried girls only apply it on their hands, though this tradition seen to be faddily nowadays. Henna on hands and feet essential for Kanuri marital process; and is equally an elegant addition to Kanuri weeding both in traditional and modern styles. However, if we look at some of the Kanuri bride, we may observe how highly some are ornamented, either with decorations or colourful designs of henna. Sometimes these designs, decorations and ornamentations characterize the honour or social status of the bride in the society.

The artistic work and selling of the ingredients are not accidental but gainful business to many people among the Kanuri in Borno and beyond. It is also significant to note in this connection that designs, and application of henna are often associated with handy artist work of women but sometimes even men. Many young girls/women use the opportunity of their leisure time to make money from decorating women mostly during festive periods and decorating brides for marriages. Henna application is work of art so there is no set pricing for it. It depends on size and intricacy of design which ultimately boils down to how much time it takes. A simple design

\footnotetext{
45 Fletcher 1912: 86 quoted by Noam Sienna 2016.

${ }^{46}$ Henna at https://allafrica.com/stories/201311260072.html accessed on 20.07.2018.
} 
starts from $\$ 1$ and can go up to $\$ 50$ or more than that for elaborated bridal henna based on the personality of the client. Yet they are highly patronized, especially by urban dwellers who make up about 80 percent of the country's population. Because of its financial benefits, even children are adequately tutored and exposed to the technique and design pattern to take over from aged and women and mothers. Also, of significance to contemporary henna application and Borno cultural values is the similarities in apprenticeship training system in the modern technique.

Henna is also medicinally applied to treat burns and blisters. It is also reported that Henna was also used to promote wound healing. Henna was associated with cleanliness and health in Ibn Qayyim Al-Jawziyya's 14th century book on herbal and medical practices. while other used it as a stain for marking animals to distinguish flocks. The root of the plant is used as a purgative; also, an abortifacient. ${ }^{47}$

\section{Recommendations}

There has been relatively little emphasis on the study of the modern techniques of henna application which the use of Rani and Sajaan from medical point of view, although its application seems to constitute a dominant part of the human society. It is therefore, recommended that researchers should carry out more empirical studies on the medical and scientific values of henna application or otherwise. However, it is pity that no economist has tried to evaluate the nature, structure, organization and economic contributions of the henna businesses in Borno. Thus, social scientist should therefore conduct research to unravel the economic mysteries behind it. Also, it is virgin area for art history research.

\section{Conclusion}

Henna application seems to be neglected field of study among the scholars such anthropologists, historians, and sociologists. In this paper we have tried to examine the application and importance of henna among Kanuri people of Borno. From the beginning the Kanuri people until they become nationally famous, they demonstrated determination in the use of simple tools, materials and design patterns in both traditional and the modern techniques. The new method reflected the cultural values and personal fulfillments in them. In our view, we have only provided the leeway for understanding the subject matter and it has been observed that henna work on all skin types and colour is a symbol or beauty part and happiness. It is

\footnotetext{
${ }^{47}$ Bargery G. P. 1951: 716.
} 
traditionally done for special occasion like holidays, birthday, naming ceremonies and weeding in Borno State. The technique has also taken adequate of modern technology; and local patronage, which contributed to continuity of its existence. The challenge therefore is how to contend with these changes where they occur without offending the soul essence of Kanuri society and their religion. Thus, we see that henna application in all its aspects has social, economic, religious, ideological as well as cultural values to both artists and users.

\section{REFERENCES}

\section{Primary sources}

Ya' Zarah Saleh, (25 years), Maiduguri, interviewed on 24/5/2014.

Aisha Muhammad Abdullahi, (21 years), Maiduguri, interviewed on 20/07/2018.

Hassana Ali, (45years), Maiduguri, interviewed on 30/06/2014.

Halima Baba Shehu, (27 years), Maiduguri, interviewed on 21/5/2014.

Ya Kaka Ari Kime, (60 years), Maiduguri, interviewed on 11/6/2014.

Ba Mammadu Daboa (30 years), Bama, interviewed on 11/06/2014.

Shiekh El-Mustapha (30 years), Maiduguri, interviewed on 20/08/2014.

Mallam Alirambe Gayibo (30 years), Maiduguri, interviewed on 20/08/2014

Karu Mala (30 years), Maiduguri, interviewed on 01/06/2014

Ya' Bawa, (30 years), Maiduguri, interviewed on 02/06/2015

Malam Muhammad Abdulqadir on phone on 1/08/2018.

\section{Secondary sources}

Babagana Kachalla Ali, The Role of Museums in Nation building: Focus on Our Material Culture and Ancient Civilization in the Borno State Museum, Maiduguri, Maiduguri: 2015.

Bargery G. P. A Hausa-English Dictionary and English-Hausa Vocabulary, London: Oxford University Press, 1951.

Bosoghu A. Burdance \& I Solmaz H. (eds). The importance of Henna Paste, 1998.

Claude Gouffe, Notes de lexicologie et d'dtymologie soudanaises III. Contacts de vocabulaire entre le haoussa et le berbere. Comptes rendus du GLECS, xvi, p. 155.173.

Funk and Wagnalls, Standard Encyclopedia, International edition, vol. 1, New York, 1965, p. 589.1

Jack R. Harlan, Origin of African Plant Domestication, Hague: Mouton Publishers, 1976. 
James Grey Jackson, An Account of Timbuctoo and Housa: Territories in the Interior Africa, Frank Cass \& Co. 1967.

J.F.Ajayi \& Michael Crowder, History of West Africa, London: Longman, 1974.

Johannes Lukas, Die Sprache der Tubu in der zentralen Sudan. Berlin: Akademie Verlag. 1953.

John M. Dalziel, A Hausa Botanical Vocabulary, London: T. Fisher Unwin Ltd., 1916.

K.B.O. Onwubiko, School Certificate of West Africa History, AD 1000-1800, Africa-FEB Publisher ltd, Onitsha: 1967.

Muhammad Nur Alkali, "The History of the Kanuri Language”, Annals of Borno, University of Maiduguri Printing Press, Maiduguri: 1987.

O. Kwame and B. Umara, "The Present Status of Kanuri and Hausa in the Maiduguri Metropolitan Council Symbiosis or Osmosis”, Annals of Borno, University of Maiduguri, University of Maiduguri Printing Press, Maiduguri: 1988.

Sunday Enessi Ododo, It's only Bent, Not Broken: Culture, Education, Politics and Performance Art in Ebira and Ogori, Nigeria: Asonta, 2014.

The American Peoples Encyclopedia, A Modern Reference Work, Grolier Incorporated, New York: 1965.

The American Journal of Medical Science, June 1980.

T. R. Lindlof \& B. C. Taylor, Qualitative Communication Research Methods, $2^{\text {nd }}$ Edition, California: Sage, 2002.

Yves Bernard \& Mary White-Kaba, Dictionnaire Zarma-Francais (Republique due Niger). Paris: Agence de Cooperation Culturelle et Technique. 1994.

\section{Internet sources}

Henna at www.hennaarts.com/henna-faq.htm accessed on 20.07.2018.

Importance of Henna among South-Asian women retrieved from www.salamstock.com

Henna and its history among Arab women, accessible at www.fashionandcustome.com

Henna at https://allafrica.com/stories/201311260072.html accessed on 20.07.2018.

Noam Sienna "Lalle, Anella, and Fudden: Henna in West Africa" eshkolhakofer.blogspot.com/2016/02/lalle-anella-and-fudden-henna-in-west.html accessed on 01.08.2018. 
APPENDIX
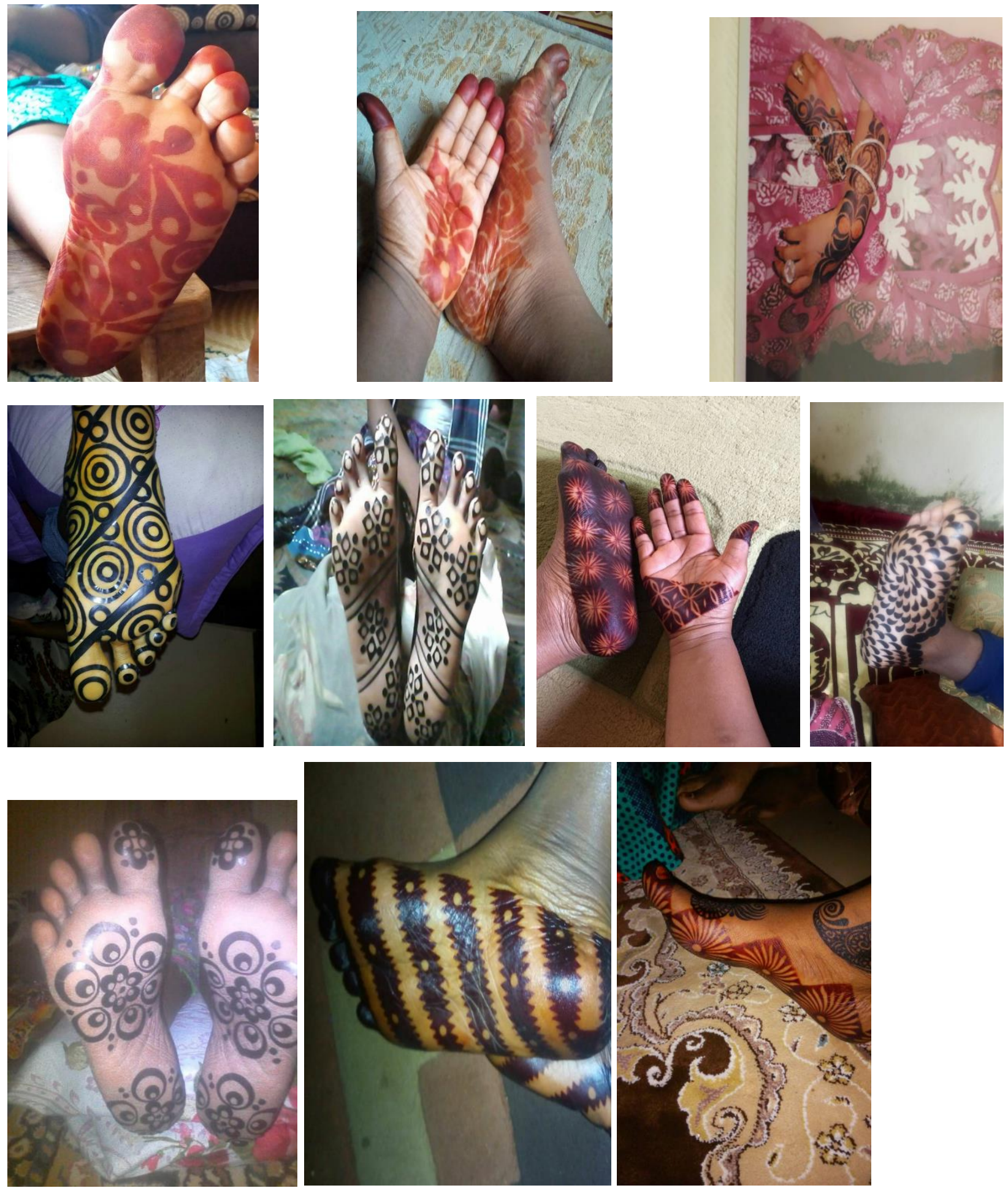


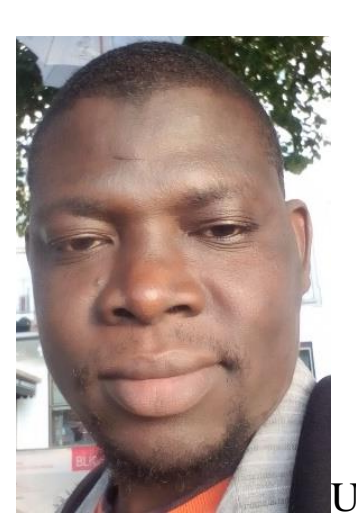

About the authors

Usman Al-amin is a lecturer in the Department of History, University of Maiduguri, Nigeria. His main fields of research include Sufism and manuscripts cultures in the context of African intellectual history, in particular, the formative period up to the 2oth century, and the historiography of Islamic sects in modern and contemporary Nigeria. He recently developed interest in the cultural history of Kanuri. He has published extensively in journals, contributed dozens of chapters to books, and presented so many academic papers in local and international conferences. In addition, he has been invited to research, write papers, and make presentations for several government functions and civil society fora. His recent researches include:

- Nguru Islamic Scholars in Perspective: The Contributions of Sheikh 'Uthmān al-Fallātī al-Ghūrāwī al-Barnāwī at-Tijânî (1909 CE/1330 AH) to Islamic Education;

- Attires for the Royalty among the Kanuri Speaking People;

- Elements of Continuity and Change in the Marriage Customs of the Kanuri Speaking People in Maiduguri Metropolis of Borno State, 1990- 2012;

- The Unknown Colonial Scars on Nigeria: The Impact of the Second World War on Nguru District (Borno Province), 1939-1945;

- The Growth of Pharmaceutical Business in Borno State, Nigeria, 1976-1999;

- The Role of Community-Based Agricultural and Rural Development Programme in Poverty Reduction in Bursari Local Government Area of Yobe State, Nigeria: 20052009 , to mention a few. 


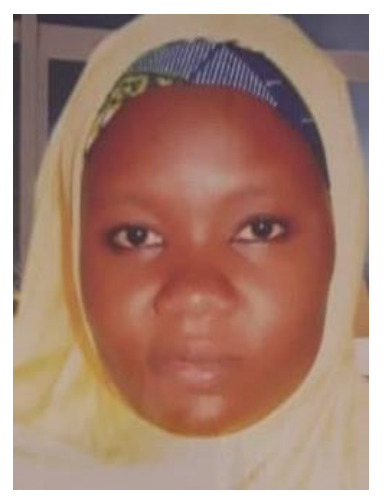

Halima Baba Shehu is also a lecturer in the Department of History, University of Maiduguri, Nigeria. Her main area of research is economic history of precolonial Borno. She also specializes in drugs and grains histories in Borno. Her scholarly publications have national and international outlets. Some her recent studies are:

- The Growth of Pharmaceutical Business in Borno State, Nigeria, 1976-1999;

- The Role of Community-Based Agricultural and Rural Development Programme in Poverty Reduction in Bursari Local Government Area of Yobe State, Nigeria: 2005-2009;

- The Unknown Colonial Scars on Nigeria: The Impact of the Second World War on Nguru District (Borno Province), 1939-1945 etc.

Abdulsalam Abba Tor and Alhaji Yakubu Babagana are also lecturers in the Department of History, University of Maiduguri, Nigeria. They specialized in International History and Diplomacy. 